\title{
An Overview : Resource Efficiency Potential in PTPN IX PG. Sragi to achieve Green Proper
}

\author{
Ifsantin Nihaya ${ }^{1, *}$, Dwi P Sasongko ${ }^{2}$, and Haryono Setiyo Huboyo ${ }^{3}$ \\ ${ }^{1}$ Magister Program of Environmental Science, School of Postgraduate Studies, Diponegoro University, Semarang - Indonesia \\ ${ }^{2}$ Department of Physics, Faculty of Science and Mathematics, Diponegoro University, Semarang - Indonesia \\ ${ }^{3}$ Department of Environmental Engineering, Faculty of Engineering, Diponegoro University, Semarang - Indonesia
}

\begin{abstract}
Program for Pollution Control, Evaluation and Rating (Proper) is an instrument to assess company performance in environmental management. To gain a green Proper appreciation of environmental management, the company must comply the requirements beyond compliance. One of the requirements beyond compliance is resource efficiency. The purpose of this study is to know the potential of resource efficiency in PTPN IX PG. Sragi to achieve Green Proper. Resource efficiency potential will be analyze use Green Proper assessment criteria. The criteria are (1) energy efficiency efforts, (2) reduction of emissions, (3) implementation of reduce and reuse of hazardous and toxic waste, (4) implementation of $3 \mathrm{R}$ non-hazardous and toxic solid waste and (5) implementation of water conservation. It is expected that by analyzing those criteria, PTPN IX PG. Sragi will consider to take necessary effort in order to improve their enviromental performance to achieve Green Proper.
\end{abstract}

Keywords: Proper; PG. Sragi; Resource Efficiency

\section{Introduction}

Industrial sector is considered as one of the guarantee of long-term economic growth that can increase income, so the Government of Indonesia keep trying to spur the growth of its industry. Although the industrial sector contributes greatly to the economy, it can also have negative effects on the environment. Negative impacts caused by the industrial sector include water pollution, soil and air [1-2]. The era of globalization has demanded the industry to improve its production system by not leaving tripple bottom line of sustainable development : economic benefits, ecological balance and business responsibility to the social environment.

In some other countries, environmental management innovations have been developed in the form of environmental information disclosure initiatives because the command and control approach is not sufficient to solve the environmental problems. In the United States, there is a Toxics Release Inventory (TRI) program that can track the management of certain toxic chemicals that can endanger human health and the environment. The industrial sectors must report the volume of each toxic chemicals that are managed as waste : recycled, managed or burned and discharged into the environment. TRI is part of a new approach to environmental protection. By making information about toxic chemical industry management available to the public, TRI creates a strong incentives for companies to improve environmental performance [3]. Other that that, one of the state in India, Maharashtra has developed the MPCB Star Rating Program. Maharashtra Pollution Control Board (MPCB) is a star rating program based on industrial PM emissions. This rating system gives one star to those who pollute the most and five stars for those who least pollute. The program aims to reduce air pollution by increasing transparency. This unique transparency initiative can change the way we think about environmental regulations [4].

In Indonesia, in order to avoid the degradation of environmental quality, the Government enacts sustainable development in accordance with Law Number 32 of 2009 on Environmental Protection and Management. This Law regulates pollution control which includes efforts to prevent, mitigate and restore environmental pollution. There are also instrument that can evaluate the company's performance in environmental management. The Ministry of Environment and Forestry issues the Proper Program, which not only complies with prevailing regulations but also added value to environmental management, resource utilization, protection of biodiversity and community development. Proper encourages corporate compliance in environmental management through

* Corresponding author : ifjikasantin@gmail.com 
incentive and disincentive instruments. Surely this is a challenge for companies to make environmental management efforts to comply with regulations. The Proper assessment criteria are components of the Green Economy. The concept of a green economy has expanded widely to respond to the need for low carbon development strategies. UNEP defines the green economy as a reconfiguration of businesses and infrastructure to generate better returns from natural resource investment, people, economic capital while reducing greenhouse gas emissions, reducing waste, reducing natural resource extraction and reducing social inequalities. Green economy means the efficient use of resources. Green economy is also mean reduction of pollution and damage to environmental degradation and community empowerment. These things are the basic principles of assessment criteria PROPER.

\section{Program for Pollution Control, Evaluation, and Rating (Proper)}

Program for Pollution Control, Evaluation, and Rating (Proper) is an instrument to assessment of enviromental performance and enviromental compliance for pollution control. Proper aims to encourage companies in Indonesia to comply with environmental regulations and achieve environmental excellence. The environmental compliance category itself is divided into two forms, beyond compliance to gold and green color indexes and compliance to regukation for blue, red and black (table 1). Companies with red and black rating means not comply to regulation, blue rating is compliance to regulation and green and gold rating are beyond compliance. Assessment criteria covers environmental documents, air and water pollution control, hazardous and toxic waste management. While the criteria beyond the compliance criteria include : implementation of environmental management system, resource utilization, protection of biodiversity and community development programs [5].

Table 1. Proper Rating based Minister of Environment Regulation No. 3 of 2014

\begin{tabular}{|c|c|c|c|}
\hline Rating & Green & Blue & Black \\
\hline Level of compliance & Beyond compliance & $\begin{array}{l}\text { Compliance to } \\
\text { regulation }\end{array}$ & Not comply \\
\hline \multirow{5}{*}{$\begin{array}{l}\text { Enviromental } \\
\text { compliance }\end{array}$} & $\begin{array}{c}\text { Environmental Management } \\
\text { System }\end{array}$ & \multicolumn{2}{|c|}{ Implementation of Enviromental Document } \\
\hline & Resource Utilization & \multicolumn{2}{|c|}{ Water Pollution Control } \\
\hline & \multirow{2}{*}{ Protection of Biodiversity } & \multicolumn{2}{|c|}{ Air Pollution Control } \\
\hline & & \multicolumn{2}{|c|}{ Hazardous and Toxic Waste Management } \\
\hline & Community Development & \multicolumn{2}{|c|}{ Control of Potential Land Damage } \\
\hline
\end{tabular}

During the last decade, the Proper participants from 2006-2017 experienced a significant increase as shown in Figure 1.

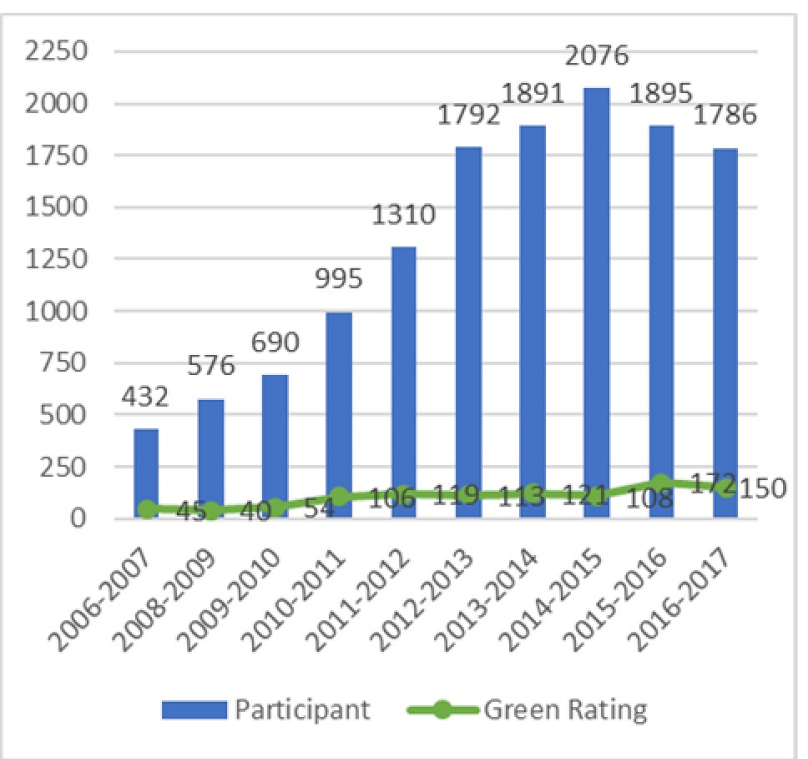

Fig. 1. Proper Participant
The number of companies that get the green Proper also increased from year to year. However, when viewed from the total participants, the Green Proper ratio only ranges between 5-10\% / year / number of participants Proper, shown in table 2.

According Handoyo, in general, the achievement of Indonesia's environmental performance from the period 2011-2015 mostly is on the blue rating. This means that environmental performance is only in compliance to regulation. Whereas general understanding says that environmental performance gained appreciation from the world community if its achievement in level beyond compliance (green and gold rating). Therefore, it is necessary to improve the environmental performance of Indonesia to a higher level [6].

Tabel. 2. Green Proper Ratio

\begin{tabular}{ccccc}
\hline No & Year & Participant & $\begin{array}{c}\text { Green } \\
\text { Rating }\end{array}$ & $\begin{array}{c}\text { Green } \\
\text { Rating Ratio }\end{array}$ \\
\hline 1 & $2006-2007$ & 432 & 45 & $10,4 \%$ \\
\hline 2 & $2008-2009$ & 576 & 40 & $6,9 \%$ \\
\hline 3 & $2009-2010$ & 690 & 54 & $7,8 \%$ \\
\hline
\end{tabular}




\begin{tabular}{ccccc}
\hline 4 & $2010-2011$ & 995 & 106 & $10,6 \%$ \\
\hline 5 & $2011-2012$ & 1310 & 119 & $9,0 \%$ \\
\hline 6 & $2012-2013$ & 1792 & 113 & $6,3 \%$ \\
\hline 7 & $2013-2014$ & 1891 & 121 & $6,4 \%$ \\
\hline 8 & $2014-2015$ & 2076 & 108 & $5,2 \%$ \\
\hline 9 & $2015-2016$ & 1895 & 172 & $9,0 \%$ \\
\hline 10 & $2016-2017$ & 1786 & 150 & $8,4 \%$ \\
\hline
\end{tabular}

The green rating Proper is a category that beyond compliance of enviromental performance. To get green Proper, must commit to do beyond compliance in order to enter and compete with other green candidates. Benchmarking green Proper candidates using criteria : Environmental management performance summary document, implementation of environmental management system, resource utilization, protection of biodiversity and community development. If the green candidates get the best $25 \%$ rating from the same group of companies that have been assessed by the Ministry of Environment and Forestry will get a green Proper rating. Industry groupings are based on similar environmental impact characteristics. Green and Gold Proper company must continue to develop innovation and excellence in environmental management, business and community development.

Based on the aspect of Proper Green Assessment, an analysis of the environmental performance of Green candidate companies is performed. From 2014-2017, the performance of Oil and Gas Exploration and Production sector company is the most prominent compared to other sector companies. Meanwhile, sugar-rubber sector company have the lowest environmental performance [7], [5], [8-9]. The purpose of this study is to analyze green Proper criteria especially to know the potential of resource efficiency in PTPN IX PG. Sragi, so PG Sragi can fulfill the criteria beyond compliance to achieve Green Proper.

\section{Material and Methode}

This study applied descriptive approach and use secondary data to be analyzed. The criteria of resources efficiency potential assessment that used in this study from Minister of Environment Regulation No. 3 of 2014. The location of the study was chosen purposively, PTPN IX PG. Sragi, a sugar factory in Pekalongan regency.

\section{Result and Discussion}

To fulfill the assessment of Proper Green (beyond compliance), one of the assessment criteria that must be meet is the resource utilization that includes energy efficiency, efforts to reduce emissions, the implementation of reduce and reuse of hazardous and toxic waste materials, the implementation of 3R nonhazardous and solid wastes and water conservation.

\subsection{Resurces Eficiency Opportunity}

PTPN IX PG. Sragi is a sugar-producing factory in Pekalongan Regency, which is included in PT
Perkebunan Nusantara IX. PG. Sragi activity involves taking sugar (sucrose) from cane and sucrose crystalyze become sugar. The process is cane milled through milling machine and then the sugarcane juice is purified to alienate the dirt and then crystallization so that the sugar is formed. Sugar production, using resources in their production process.

Paying attention to environmental sustainability can used as a driving factor for the company to innovate, create values and build a competitive advantage. The Proper criteria are designed to encourage companies to achieve competitive advantage. The efficiency of resource use is driven by energy efficiency, reduction of emission, implementation of water conservation, reduce and reuse of hazardous and toxic waste and $3 R$ (reduce, reuse and recycle) of non-hazardous solid waste. With more efficient utilization resources, then Proper encourages the company to set aside some of these resources for the surrounding community with community empowerment programs.

Proper aims to encourage companies to implement a good system in management environment. If the system is owned by the company already good, then the company can improve efficiency in waste reduction. After having data, then company can compare the results obtained with other companies' absolute results (benchmarking). It is useful to know the position of the company, whether it is the most efficient or not. From there expected to emerge innovations for make more improvements.

\subsection{Resources Efficiency Potential}

\section{Energy efficiency efforts}

Energy efficiency is an attempt to use less energy in running a process with the same performance. This can be achieved in several ways, including with efficient usage behavior, good care, the use of energy-efficient equipment, and the reuse of wasted energy. The dominant energy type used for production activities of PTPN IX PG. Sragi is the steam energy for milling and evaporation processes. Where this steam is obtained from a boiler steam fueled by bagasse. The amount of savings that can be done is very dependent on the form of effort that conducted. In addition to savings in terms of energy costs, energy efficiency can also improve the competitiveness of an industrial product. The energy efficiency activities assessed in the Proper valuation criteria are the company's efforts to improve the efficiency of energy consumption through efficiency improvement activities, Retrofit (replacement / repair) of environmentally friendly equipment, building efficiency, efficiency in the transport system. A preliminary review or an energy audit is the first step to be taken to determine the inefficiencies available, for the preparation of the austerity targets, and the determination of potential savings to be achieved. After the audit is done, the rational target is determined and then proceed with the preparation of the action plan and its implementation. 


\section{Reduction of emissions}

The reduction of air pollution included in the scope of Proper assessment is all the activities undertaken by the company to reduce air pollution emissions to the environment and such efforts do not cause significant pollution to other media. Air pollution referred to above is the conventional air pollution parameters of sulfur dioxide, particulates, hydrocarbons, hydrogen sulfide and greenhouse gas parameters of carbon dioxide, methane, nitrogen oxide and fluorinated gas (ozone depleting substances). Emissions generated by PG. Sragi comes from chimney boilers, sulfitasi chimneys and diesel generator chimneys. Efforts that need to be made to meet the criteria of emission reduction assessment, among others : 1) Have energy conservation and air emission reduction programs, 2) Conduct audits of energy use and control of air emissions, 3) Having a balance of energy usage, 4) Conducting fugitive emission reduction activities. 5) Conducting activities to reduce the use of ODS (ozone depleting substances), 6) Conducting GHG reduction activities, 7) Perform energy efficiency, and 8) Have a balance of energy usage

\section{Implementation of reduce and reuse of hazardous} and toxic waste

The implementation of 3R (Reuse, Reduce, and Recycle) systems is one of the solutions in maintaining the work environment in and around the company. Implementation of hazardous and solid waste reduction can be done by minimizing the use of oil, so residual oil which is a hazardous and toxic waste can be reduced. This must be proven with reuse and reduce program and reuse and reduce effort with technological innovation. In its operational activities, PG. Sragi can prioritize the principle of reduction at source (reduction at source) as done by PT. Perusahaan Gas Negara (Persero) Tbk is to minimize the incidence of waste. Minimization can be done from reducing the quantity and impact. Examples of efforts made: the replacement of lights containing mercury with LED lights gradually so as to reduce the amount of hazardous and solid wastes [10].

\section{Implementation of 3R non-hazardous and toxic solid waste}

One of the non-hazardous and solid wastes produced by PG. Sragi is filter cake or filter press mud, which comes out of the process in solid form contains water and still has a high temperature, shaped like soil, is actually sugarcane fiber mixed with dirt separated from sugarcane juice. The accumulation of such material in large quantities will be one source of environmental pollution. According to Prasad in Muhsin A, 2011, Blotong contains organic colloidal material dispersed in sugarcane juice and mixed with organic and inorganic anions [11]. Filter cake consists mostly of cane fibers and is an important source of organic fertilizer for the formation of soil humus.

Besides filter cake, bagasse is a residue from sugar cane milling process after the juice being extracted or expelled. Sugarcane waste is a fibrous waste product and has a high hygroscopic level. According to Misran (2005), Sugar factory produced around $35-40 \%$ bagasse from every processed cane. The baggase, by PG. Sragi is used as a boiler fuel. It is included in the reduction of non-hazardous and solid wastes [12].

Waste management can be carried out through reuse the waste. Reuse is utilization of waste for the same or other functions One of the implementation is reuse filter cake and bagasse to other function.

\section{Implementation of water conservation}

Water is the key to the processing of food products. In the food industry, water is used in various operating purposes such as washing, boiler feed, and indirect cooling. In addition there is also water that is directly mixed into the food ingredients. Sugar production is a process that requires intensive water. Here are some efforts to conserve water, including : 1 ) Conduct an audit of water use, 2) Having a water use balance for all water used, 3) Conduct 3R efforts for waste water and 4) Efforts to make efficient use of water.

\section{Conclusions}

From the above discussion, it can be seen that to get Proper green, PTPN PG. Sragi need to meet the criteria beyond compliance, one of the criteria is the utilization of resources. It is expected that by know the resource efficiency potential, PTPN IX PG. Sragi will make the necessary effort to improve their environmental performance especially the efficiency of resources to achieve Proper green.

\section{References}

1. W.E. Cahyono. Kajian Tingkat Pencemaran Sulphur Dioksida Dari Industri Di Beberapa Daerah Di Indonesia. J. Berita Dirgantara 12, 4 : 132-137 (2011)

2. S. Supraptini. Pengaruh Limbah Industri Terhadap Lingkungan di Indonesia. Media Penelitian dan pengembangan Kesehatan 12, 2 : 10-19 (2002)

3. https://www.epa.gov/toxics-release-inventory-tri-pr ogram/learn-about-toxics-release-inventory.access ed on July 10, 2018

4. V.M. Motghare. MPCB's Landmark Star Rating Program. Seminar on Managing Industrial Emission (2018)

5. KLHK. Publikasi Proper 2015. Kementerian Lingkungan Hidup dan Kehutanan. (2015)

6. S. Handoyo. The Development of Indonesia Enviromental Performance and Enviromental Compliance. Journal of Accounting and Business. 1, $1: 74-85$ (2018)

7. KLHK. Proper 20142 Dekade Proper Tingkatkan Ketaatan, Pacu Efisiensi, Dorong Inovasi, Berdayakan Masyarakat. Kementerian Lingkungan Hidup dan Kehutanan. (2014)

8. KLHK. Publikasi Proper 2016. Kementerian Lingkungan Hidup dan Kehutanan. (2016) 
9. KLHK. Proper 2017 Creating Value Kolaborasi Pemerintah, Dunia Usaha dan Masyarakat. Kementerian Lingkungan Hidup dan Kehutanan. (2017)

10. PGN. Laporan Keberlanjutan Sustainability Picture. PT. Perusahaan Gas Negara (Persero) Tbk.
(2017)

11. A. Muhsin. Pemanfaatan Limbah Hasil Pengolahan Pabrik tahu Blotong Menjadi Pupuk Organik. Industrial Engineering Conference. (2011)

12. E. Misran. Industri tebu menuju zero waste industry. Jurnal Teknologi Proses 4, 2 : 6-10 (2005) 